\title{
Raphe like vestiges in the pennate diatom suborder Araphidinae?
}

\author{
H. Lange-Bertalot ${ }^{1}$ \\ R. Le Cohu²
}

Kevwords : Freshwater, Diatoms, Fragilaria, Achnanthes, pore, slit, raphe, like-vestiges, septum, Kerguelen, Wyoming.

\begin{abstract}
Raphe-like vestiges have been found regularly in two new taxa which presumably belong to Fragilaria, one of them living in several lakes of the Kerguelen Islands, the other in the Yellows tone National Park, Wyoming, U.S.A. The latter one porsesses seplat-like elements as integrated parts of a girdle band. Other septa-like elements can occur in different species of Fragilaria. They represent appendices of the valvocopula, located beneath the transapical costae. Structures like linking spines on marginal parts of the valve face occur in an Achnanthes species. Most of these characters seem to have been unknown in these taxa until recently.
\end{abstract}

Diłtomées pennales avec des vestiges de raphés : un sous-ordre des Araphidinées ?

Mnts clés : eau douce, diatomées, Fragilaria, Achnanthes, pore, fente, vestiges de raphé, septum, Kerguelen, Wyoming.

Des vestiges de raphé ont été observés régulièrement chez deux nouveaux taxons appartenant probablement au G. Fragilaria. L'un d'eux a été rencontré dans plusieurs lacs des îles Kerguelen, l'autre dans le parc national de Yellowstone. Wvoming, Etats-Unis. Ce dernier présente des structures de type septum intégrées à la ceint ure connective, structures pouvant être observées chez différentes espèces de Fragilaria. Elles représentent des appendices de la valvo-copula, placés au-dessous des côtes transapicales. Un système d'indentations semblant permettre l'agrégation des frustules est signalé chez un Achnanthes. Jusqu'à maintenant, la plupart des caractères précités semblent inconnus chez ces taxons.

\section{Introduction}

In two previous papers it has been shown that ravheless valves of different Achnanthes species exhibit slits of different lenght in distal parts of the valve faces and in addition the presence of terminal, in one case terminal and central pores (Le Cohu \& Maillard 1983, Krammer \& Lange-Bertalot 1985). Less distinct vestiges were documented in Achnanthes linkei Hustedt by Andrews (1981) and generally mentioned by Simonsen (1979). These vestiges were discussed as rudiments or (less probably) precursors of true raphes which otherwise were fully developed in the opposite valve of each frustule. In all different species of the Kerguelen Island these vestiges

1. Botanisches Institut der I.W. Goethe-Universität, Siesmaverst. 70. Postfach $111932 \cdot 6000$ Frankfurt a.M. (R.F.A.).

2. Laboratoire d'Hydrobiologie U.A. 695 C.N.R.S., Universite P. Sahatier, 118 route de Narbonne, 31062 Toulouse, France. are comparatively poorly developed whereas in the emended Achnanthes bioretii Germain they have more similarity with normal raphes and therefore many populations or individuals of this taxon have been taken for a Navicula, in particular Navicula rotaeana, by many authors. Meanwhile we could trace out comparable structures of different extent in many other species of Achnanthes. Moreover, we introduce two new taxa exhibiting raphe-like vestiges, to all appearance belonging to the subfamily of the Fragilarioideae, however, not without doubt to Fragilaria.

\section{Observations}

1. Fragilaria maillardii Le Cohu nov, spec. (Fig. 1/3, 18/23, 24)

In four lakes (Lac Alicia, Lac des Korrigans, Lac des Sternes, Lac Studer) of the Kerguelen Islands in 
the subantarctic region of the Indian ocean, one of us found populations of an up to now unknown taxon. Most of the morphological characteristics point to Fragilaria, in particular to the taxonomically problematic group of forms around $F$. construens. In LM no significant difference can be found to separate it from populations which are usually determined by many authors as $F$. construens var. venter (Ehrenberg) Grunow or as F. elliptica Schumann. Without having controlled the type material of Ehrenberg or Schumann, respectively, and without knowledge of the morphologic variability of taxa around $F$. consiruens, including varieties and formae, no more distinctive determination seems to be possible in any case. The valves are mounted with linking spines on the margins similar to those of the so-called Fragilaria elliptica demonstrated by Haworth (1975, Sem Fig. 14/21), somewhat less similar to those of Archibald (1983, Fig. 519/522) where the spines are directly situated on the striae (on intercostae in SEM), and moreover the foramina become larger nearer to the margins. Compare our LM and SEM figures on plate 1 and 2 representing Fragilaria elliptica in contrast with $F$. construens var, venter. The outline of specimens of the new taxon varies from elliptical to linear with approximately bluntly rounded apices. The striae consist on each side of the axial area of simple rows of \pm 4-7 round foramina, respectively areolae, on the valve face running without interruption somewhat over the mantle. The axial area is linear-elliptical, more or less enlarged in the central part. Neither a rimoportula nor apical pore fields can be detected. However, every valve shows near the apices, inside and outside, apical running ${ }^{ \pm}$short slits or apically elongated pores, comparable to reduced raphe branches in the aforementioned rapheless valves of $A c h$. nanthes or the typically shortened ones of Rhoicosphenia. In some cases a terminal pore seems to be developed.

Diagnosis. Holotypus : Coll. Le Cohu Kerg. Korr. $n^{\circ} 23$.

Type locality: Kerguelen Islands, Lac des Korrigans.

This species is dedicated in honor to R. Maillard, diatomist, Evreux.

In L.M. : Nulla significans differentia inter haec species et Fragilaria construens var. venter aut Fragilaria elliptica. Valva elliptica vel Linearis cum rotundis apicibus. In SEM : marginales spinae in transapicalium costarum productione. Striae cons. titutae simplici ordine a 4 ad 7 circinitas foraminas quae continuant sine intermissu ad limbum. Area axialis linearis-elliptica dilatata in media parte. Rimoportulae et porum apicalis area absentes. In apicale parte axialis areae, in valvarum interiore et externo, praesentia pororum, saepe procerarum rimarum forma; pori similes vestigits raphium observatis apud aliquuos Achnanthes aut recisis ramis raphis apud Rhoicosphenia curvata.

2. Fragilaria loetschertii Lange-Bertalot nov. spec. (Fig. 13/17, 30/34) and Krammer \& Lange-Bertalot 1985 (Fig. 32, 13, 33.1/5, 34.1/2)

A population of a second new taxon was found in the Firehole River of the Yellowstone National Park, U.S.A. The SEM-structure of the specimens is less similar to established taxa of Fragilaria in contrast with the Kerguelen populations. Beside regularly occurring raphe-like polar slits on both valves of a frustule, it is the presence of a peculiar connecting band with septa projecting unilaterally into the interior of the frustule. These septa are gradually reduced in length from one valve apex to the other. In LM the specimens can hardly be distinguished from Fragilaria pinnata, however, in SEM the distinct double (locally three) rows of areolae of each transapical stria are a third morphologic character differentiating this taxon from $F$. pinnata and other known species of this genus. Frustules in girdle view forming ribbon-like chains. Valves elliptical to linear-elliptical, rarely slightly ovate, with broadly rounded apices, ca. $6 \cdot 14 \mu \mathrm{m}$ long, ca. $4-6 \mu \mathrm{m}$ wide. Axial area narrow, linear. Striae coarse, parallel in the centre, radiate towards the apices of the valve, 6-12/10 $\mu \mathrm{m}$. In SEM : linking-spines arranged near the edge on transapical costae. Simple or bifurcate tips of the spines touching the transapical striae of an adjacent frustule. Each stria is formed of double (rarely three) rows of foramina. Each valve face of a frustule, outside and inside, with raphe-like short slits near the apices. Rimoportulae or apical pore fields absent. Connecting band with septa unilaterally in the frustule.

Diagnosis. Holotypus : Coll. Lange-Bertalot nor. AmN 10 .

Type locality : U.S.A., Wyoming, Yellowstone Nat. Park, Firehole. 
River, 5.6.1983, Leg. Ute Rumrich.

This species is dedicated in honor to my colleague, late Dr. Wilhelm Lötschert, ecologist in Frankfurt-am-Main.

Frustula e facie connectivali reclangulares, catenos congestas formantes. Valvae ellipticae usque ad lineari-ellipticae, raro leniter claviformes, apicibus late rotundatis, circiter $6-14 \mu \mathrm{m}$ longae, $4-6 \mu \mathrm{m}$ latae. Area axialis anguste linearis. Striae transapicales in partibus medianibus valvae parallelae ad polos versus radiantes, $6 \cdot 12 / 10_{\mu} \mathrm{m}$. In SEM : marginales spinae in transapicalium costarum productione cum simplicibus aut bifurcis extremitatibus quae continjunt confinis frustulae transapicales strias. Striae constitutae duabus ordinibus (raro 3) foraminarum. In valvarum interiore et extemo, frons cum brevibus rimis in axialis areae extremitate. Nulla rimopor. tula nulla porum apicalis area. Pleura cum septis uno latere in frustulae interiore.

\section{Discussion}

A more or less extensive reduction of the branches of the raphe is characteristic for a few species of Novicula which regularly develop ribbon-like chains as for instance, Navicula gallica. Thus, in some cases, taxa of Navicula have originally been mista. ken for Fragilaria. The new taxa, however, share more similarities with Fragilaria than Navicula, taking into consideration all characters in LM and SF.M. In these cases neither artefacts nor teratologiral or morphological irregularities play a role. Artually we have no possibilities to prove, whether the raphe-like slits can function for moving or not. Otherwise, this information is also missing in many other cases of taxa with unquestionable relationshin to typical Raphidineae as Naviculaceae or Achnanthaceae. If we would have found only one population, in particular that with the asymmetric arrangement of septa on the connecting band, the idea of an independent new genus or even a new family would be more plausible. However, the populations of the Kerguelen show little difference from some infraspecific taxa of Fragilaria construens, except the a apically elongated terminal pores". This fact supports more the idea that Fragilarioideae or even Fragilaria possess more morphologic capabilities than anticipated by taxonomists up to recently. Thus. Simonsen $(1974,1979)$ pointed to Araphidineae as a group which has largely been neglected by taxonomic and morphologic work and he states that our ignorance makes them the weak link in the Pennales. Moreover it should be re-evaluated, whether or not the bipartition of the Fragilariceae (" Diatomaceae ") into Tabellarioideae and the Fragilarioideae is tenable by the traditional criteria like the formation of septa.

Both new taxa which are combined here with $\mathrm{Fra}$ gilaria - maybe in a provisional arrangement - are lacking any rimoportula and apical pore fields. As known so far, the first is a species-specific facultative character in the subfamily. The latter, however, seems to be an obligatory one, except for single specimens among a population where it might be apparently absent, rudimentary or not to discern without difficulty.

With respect to septa, we find in typical populations of Fragilaria pinnata and $F$. construens f. venter flat projections of different lengths protruding into the valvar plane of the frustule (Fig. 39/40). On the other end, linking spines which are a very abundant character (though not obligatory) in Fragilaria seemed to be absent in Achnanthes: nevertheless, Le Cohu \& Maillard (1983) observed indentations in the same position as on valves of Fragilaria in Achnanthes lanceolata (Bréb.) Grun. var. lanceolatoides (Sov.) Reim.

Now we found a specimen (Fig. 42) of Achnanthes exhibiting linking spines or adequate elements in the same position as on valves of Fragilaria or sometimes of Navicula or, very rarely of Pinnularia. The specific taxonomic identification is difficult. Probably it belongs into the very problematic group of populations around Achnanthes marginulata Grunow.

The general conclusion is that the occurence of uncommon (unknown) combinations of characters in Diatom genera should induce a re-examination of recent definitions even of higher taxa.

\section{Acknowledgements}

We gratefully acknowledge the help rendered us by Dr. Kurt Krammer and Mrs Ute Rumbrich. The electron microscopic work was carried out by Mr. Manfred Ruppel (Bot. Inst. Frankfurt), R. Le Cohu (Toulouse) and Dr. Kurt Krammer, Düsseldorf (Pl. III, Fig. 1/2). 


\section{Travaux cités.}

Andrews (G.W.). 1981. - Achnanthes linkei and the originin of monoraphid Diatoms. Bacillaria, 4: $29-40$.

Anonvmous, 1975. - Proposals for a standardization of diatom terminology and diagnoses. Nova Hedwigia, suppl. 53 : 323-354.

Arrhibald (R.E.M.). 1983. - The Diatoms of the Sundays and Great Fish Rivers in the Eastern Cap Province of South Africa. Bibl. Diatomologica, $1: 1-432$

Haworth (E.). 1975. - A Scanning electron microscope study of some different [rustule forms of the genus Fragilaria found in Scottish Late Glacial sediments. Brit, phycol., J., $10: 73.80$.

Le Cohu (R.) \& Maillard (R.). 1983. - Les diatomées monoraphidées des iles Kerguelen. Annis Limnol, 19 (3) : 143.167.
Krammer (K.) \& Lange-Bertalot (H.). 1985. - Naviculaceae. Neue und wenig bekannte Taxa, neue Kombinationen und Synonyme suwie Bemerkungen zu einigen Gattungen. Bibl. Diatomologica (in press).

Ross (R.), Cox (E..J.), Karayeva (N.I.), Mann (D.G.), Paddock (T.B.B.), Simonsen (R.) \& Sims (P.A.). 1979. - An amended terminology for the siliceous components of the diatom cell. Nova Hedwigia, suppl. 64: 513.533.

Simonsen (R.). 1974. - The diatom plankton of the Indian Ocean Expedition of R/V Meteor 1964-1965. Meteor Forsch. Ergeb. nisse, ser. D, 19:1-107.

Simonsen (R.). 1979. - The diatom system : ideas on phylogeny. Bacillaria, $2: 9.71$. 


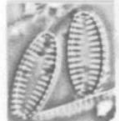

1

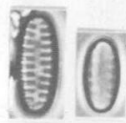

11

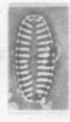

2

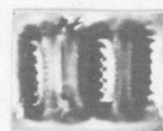

13

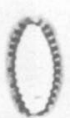

4

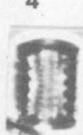

14

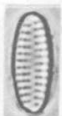

5

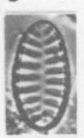

15

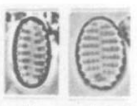

6

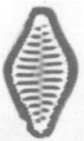

8

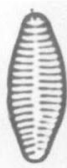

9

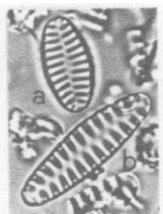

10
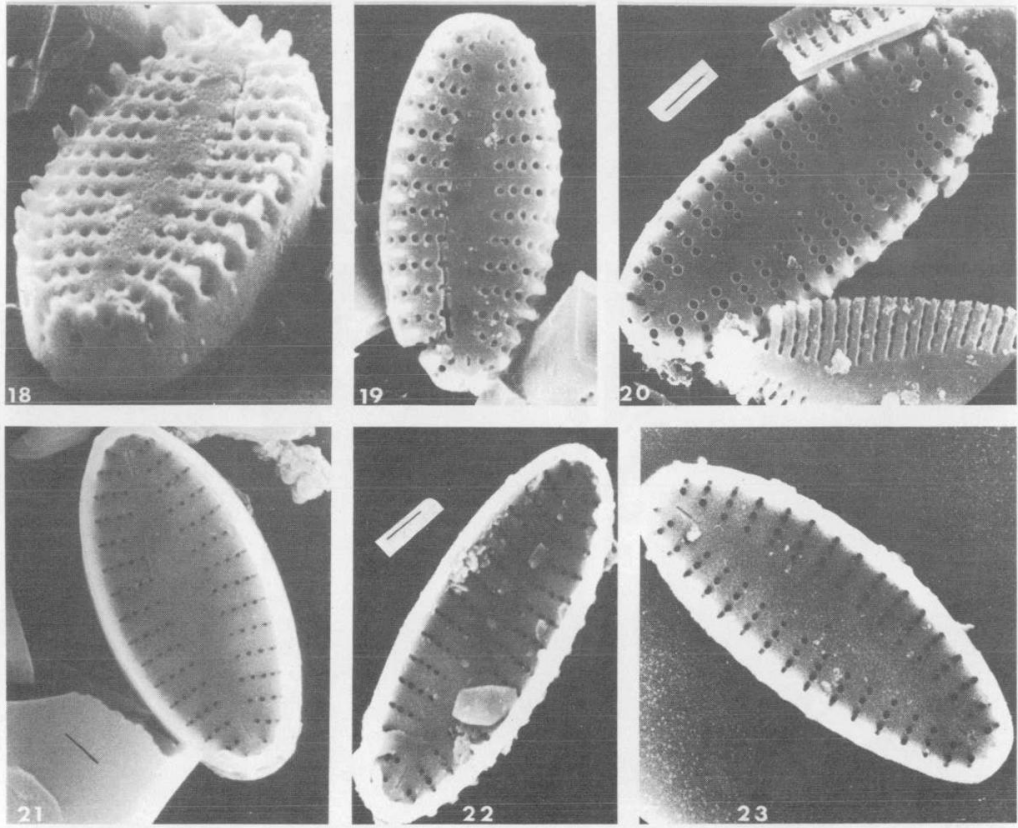

Plate I : (Fig. 1/17 LM × $1500 ;$ Fig. 18/23 SEM × $11000, \times 7000, \times 7000, \times 6000, \times 6500, \times 7000) . S c a l e$ LM:10 $\mu \mathrm{m}$, SEM : $1 \mu \mathrm{m}$.

Fig. 1/3: Fragilaria maillardii nov. spec. ; 4/7:Fragilaria elliptica Schumann (Linking spines discernible directy on the punctate striae) ; 8/10a : Fragilaria construens f. venter (Ehrenberg) Hustedt ; 10b/12: Fragilaria pinnata Ehrenberg (12: valvo-copula with faintly discernible septa-like appendices); $13 / 17:$ Fragilaria loetschertii nov. spec., ; $18 / 23:$ Fragilaria maillardii nov. spec. (18/20 : valve outside with linking spines on transapical costae and with elongated terminal pores : $21 / 23$ : valve inside with somewhat more elongated raphe-like vestiges). 

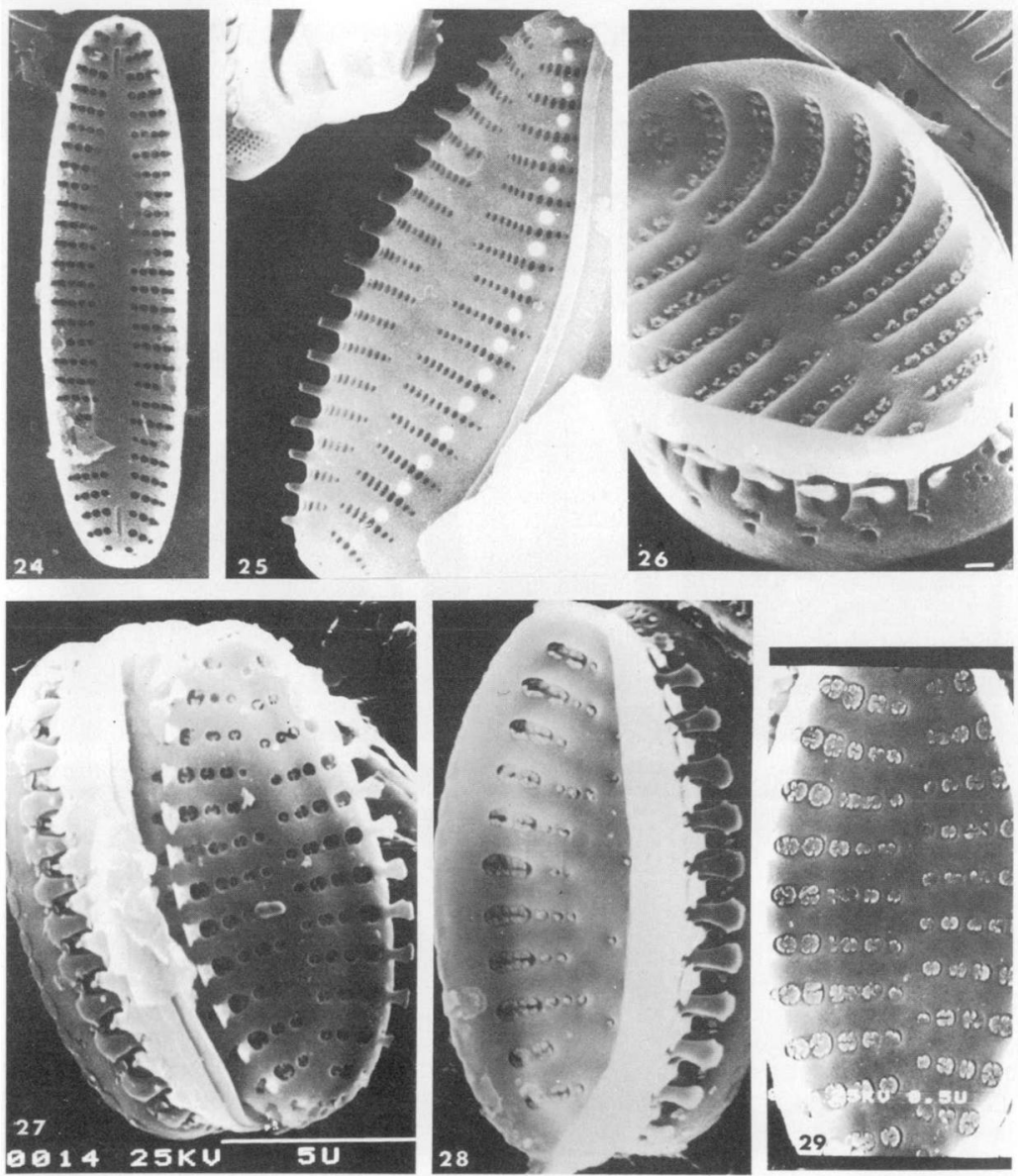

Plate II $:($ SEM $\times 5000$, ca. $\times 6600$, ca. $\times 11000$, ca. $\times 7000$, ca. $\times 7000)$

Fig. 24 : Fragilaria maillardii nov. spec. (valve inside); $25 / 26:$ Fragilaria construens $f$. venter $(25$ : valve outside with linking spines arranged on transapical costae and small apical pore field ; 26 : valve inside with closing structures on uniformly large areolae); $27 / 29$ : Fragilaria elliptica $(27$; valve outside with linking spines characteristically arranged on marginal intercostae ; $28 / 29$ : valve inside with closing structures on areolae with decreasing size towards the axial area). 

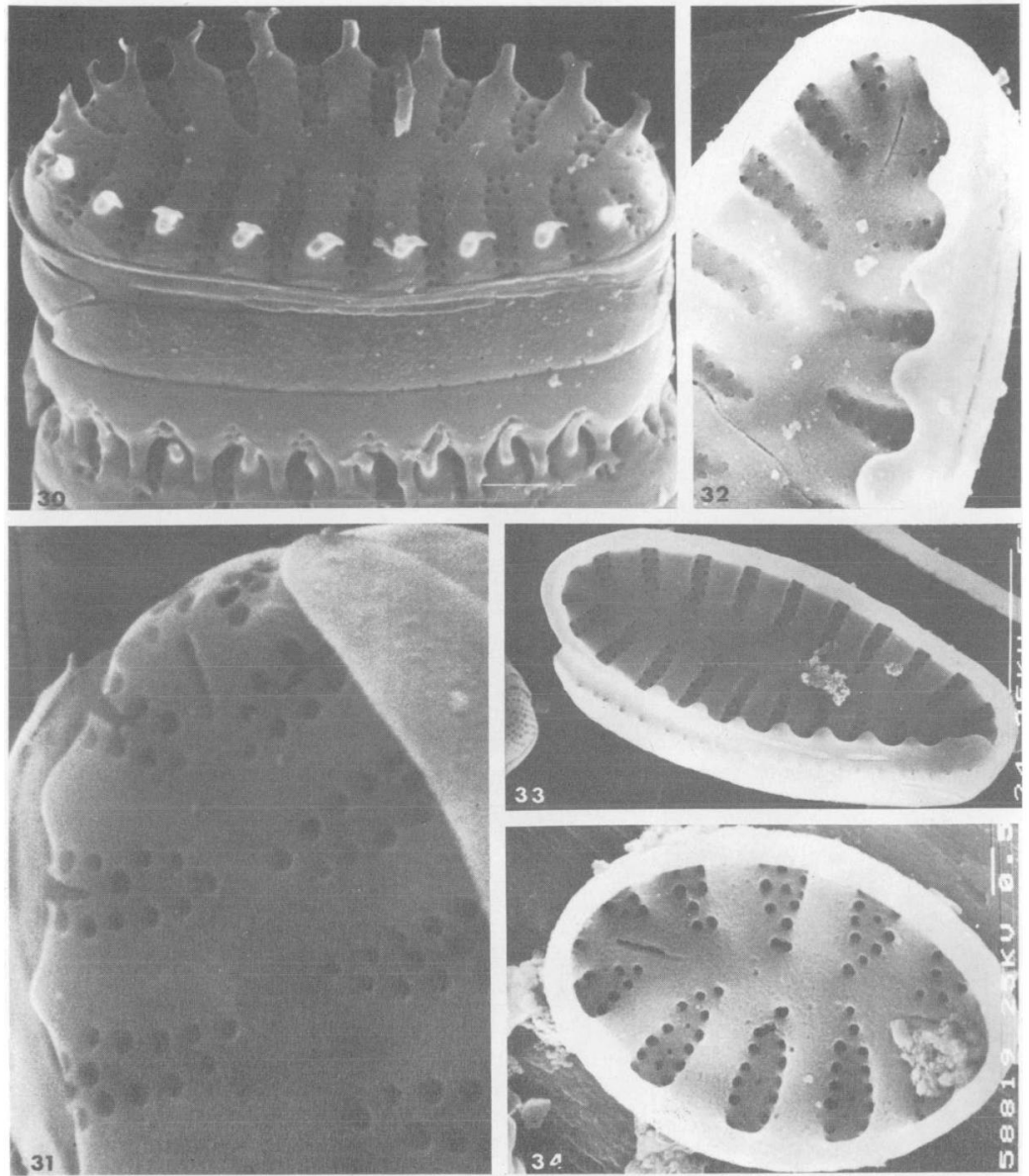

I'ilte III $:(S E M \times 10000, \times 24000$, ca. $\times 15000$, ca. $\times 5000$, ca. $\times 13000)$.

Fig. 30/34: Fragilaria loetschertii nov. spec. (30: adjacent frustules in girdle view with girdle band, linking spines on transapical costae, double rows of foramina, terminal raphe-like slits present, rimoportula and special apical pore fields absent ; 31 : enlarged apical structures ; $32 / 34$ : valves inside with terminal slits and unilateral asymmetric septa-like elements respectively). 

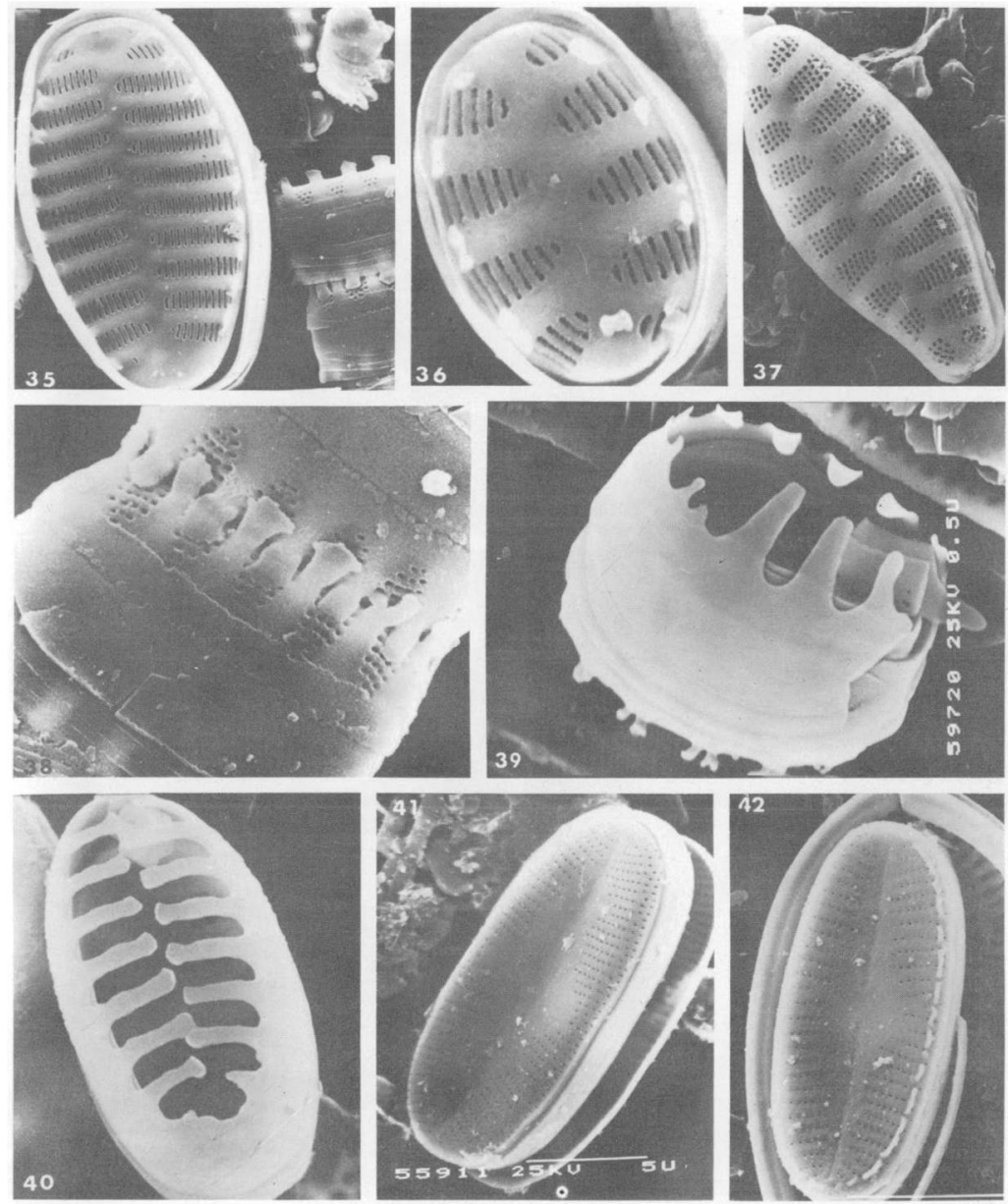

Plate IV : (SEM ca. $\times 4800$, ca. $\times 11000$, ca. $\times 6000$, ca. $\times 11000$, ca. $\times 8000$, ca. $\times 9000$, ca. $\times 4000$, ca. $\times 5000)$.

Fig. 35/39 : Fragilaria pinnata (35: "Opephora-martyi w-form with comparatively wide valve dimensions and linking spines on transapical costae, the fragment right below represents the same population as figure $38: 36:$ comparatively small pinnata-form with grill-shaped foramina; $37:$ other pinnata-population with grid-like foramina and linking spines on intercostae comparable with Opephora pacifica; 38 : other population with linking spines on transapical costae ; 39 : frustule fragment, valvocopula above with septalike appendices juxtaposed to the transapical costae) $; 40$ : presumable Fragilaria construens $\mathrm{f}$. venter (generally same structures as in figure 39 ) ; 41 : Achnarthes aff. marginulata (normal rapheless valve without linking-spines); 42 : Achnanthes aff. marginulata (rapheless valve with marginal tinking spine-like elements). 